\title{
External technology commercialisation as an alternative mode of technology marketing
}

\author{
Ulrich Lichtenthaler
}

Otto Beisheim School of Management (WHU)

Burgplatz 2, D-56179 Vallendar, Germany

E-mail: lichtenthaler@whu.edu

\begin{abstract}
External Technology Commercialisation (ETC) refers to the commercialisation of disembodied technological knowledge, either exclusively or in addition to its application in own products of a firm. Recently, a few firms have realised enormous benefits by externally leveraging technology assets. Most firms, however, experience major difficulties when they try to actively use the external mode of technology marketing. Despite these difficulties, a substantial increase in ETC could be observed during the last years. Therefore, the present paper focuses on ETC as a complementary mode of technology marketing to balance the focus of prior works on the application of technology inside the firm. Based on an analysis of the existing literature, the characteristics of the ETC perspective are detailed, and the strategic and monetary functions of ETC are examined. Then, an integrated approach to technology marketing is developed, which may help to explain the contradictory situation of enormous benefits and major managerial difficulties in ETC. A more holistic approach is particularly relevant due to the strong interdependencies between internal and external technology exploitation. Finally, the implications of an integrated technology marketing approach for research and practice are discussed, and suggestions for further research are given.
\end{abstract}

Keywords: technology marketing; external technology commercialisation; external technology exploitation; licensing; technology transfer.

Reference to this paper should be made as follows: Lichtenthaler, U. (2006) 'External technology commercialisation as an alternative mode of technology marketing', Int. J. Technology Marketing, Vol. 1, No. 4, pp.411-430.

Biographical notes: Ulrich Lichtenthaler is a Research Associate at the Chair for Technology and Innovation Management at Otto Beisheim School of Management (WHU), Germany. He received a Master's Degree in International Business Administration from the University of Bamberg, Germany, and a European Master of Business Sciences from the University of Granada, Spain. His research interests include technology strategies, knowledge management and inter-organisational alliances. 


\section{Introduction}

In recent years, competition has become increasingly knowledge-based (Ruggles, 1998; Amesse and Cohendet, 2001; Scarbrough and Swan, 2001), above all in technology-intensive industries (Granstrand, 1998; Lan, 2000). In addition to this growing importance of knowledge in general, technology transactions between firms and their environment have increased substantially (Brockhoff et al., 1991; Veugelers, 1997; Davis and Harrison, 2001). As a result, firms not only have to build up the ability to manage technological knowledge inside their organisations (Grant, 1996; Ernst, 1998; Hansen, 2002; Hoegl et al., 2003). Instead, companies also need the ability to manage the acquisition and emission of technologies to realise the potential of their technology portfolios and to successfully manage the technology transactions (Ford, 1988; Chesbrough, 2003a). Due to the imperfections of the markets for technology, which have been addressed in detail in prior research, technology transactions are much more difficult and complex than transactions in the markets for most products and services (Teece, 1981; Bidault and Fischer, 1994; Brockhoff, 1999b; Arora et al., 2001b).

Despite these difficulties, many firms have actively acquired external technology since the 1990s (Granstrand et al., 1992; Kurokawa, 1997; Veugelers and Cassiman, 1999). Only in recent years, however, the external exploitation of technologies has become a stronger trend in practice (Arora, 1997; Gans and Stern, 2003; Kline, 2003). External Technology Commercialisation (ETC) is understood as the commercialisation of disembodied technological knowledge. Thus, it refers to the commercialisation of knowledge instead of the commercialisation of products or services. Increasingly, firms consider this external exploitation mode a proactive activity, which may include all technology assets. Thus, it goes far beyond a residual activity of commercialising technologies that are not used in internal operations (Rivette and Kline, 2000b; Amesse and Cohendet, 2001). The recent increase in ETC activities is primarily a trend from practice, which has been pioneered by a few large firms, such as IBM (Kline, 2003). Some of these firms realise annual licensing revenues of more than \$US1 billion (Rivette and Kline, 2000b; Davis and Harrison, 2001).

By contrast, scientific interest in ETC has grown only recently (Tschirky et al., 2000; Granstrand, 2004; Koruna, 2004). Research into technology marketing has largely focused on the commercialisation of technologies in the own products and/or services of a firm (Nevens et al., 1990; John et al., 1999; Hwang, 2004; Uslay et al., 2004). The external mode of commercialising technology via transferring disembodied knowledge, e.g., through licensing agreements, has often been neglected. Interestingly, some early works (e.g., Teece, 1981; Ford, 1985; 1988) have addressed this topic, and they have partly used the term 'technology marketing' specifically to describe the commercialisation of disembodied technological knowledge. After these early contributions, however, there has not been a continuous stream of research into ETC, and the relevant literature is highly fragmented.

Currently, two facts underline the need for further research into ETC:

1 ETC is increasing against the background of the imperfections inherent to the markets for technology (Kline, 2003; Guilhon et al., 2004; Koruna, 2004).

2 Many firms experience substantial difficulties in managing these activities (Sullivan and Fox, 1996; Elton et al., 2002; Birkenmeier, 2003). 
Therefore, it is the aim of the present paper to put emphasis on the external mode of technology marketing to facilitate a more balanced approach to the commercialisation of technologies in both research and practice. Based on an analysis of the major functions of ETC activities, the strong interdependencies between internal and external technology marketing are demonstrated. Accordingly, an integrated approach to technology marketing is developed, which may help to explain the discrepancies between the few very successful firms and the many rather unsuccessful firms in ETC. These discrepancies may not be explained by prior research. The object of analysis is ETC activities at the firm level. The focus is on firms whose main business is internal technology exploitation, i.e., the commercialisation of technologies in own products and/or services, and not on firms that mainly provide R\&D services (e.g., Chiesa et al., 2004).

The remainder of the paper is structured as follows. In the next section, the perspective of ETC as an alternative mode of technology marketing is described. Then, major functions of ETC activities are addressed. This analysis helps us to understand what drives firms to externally leverage technology assets and in what situations this external mode of technology marketing appears to be particularly beneficial. Afterwards, an integrated approach to technology marketing, which includes internal and external commercialisation activities, is established. This integrated perspective facilitates a deeper understanding of the strategy space in technology marketing against the background of increasingly open approaches to innovation (Chesbrough, 2003a). Eventually, the implications of our analysis for research and practice are discussed before arriving at a conclusion in the final section.

\section{The perspective of external technology commercialisation}

The perspective of actively managing ETC as the commercialisation of disembodied technological knowledge was first adapted in the 1970s (Ford and Ryan, 1977; Anderson, 1979; Lien, 1979; Marcy, 1979). Above all through the works of Ford (Ford and Ryan, 1977; 1981; Ford, 1985; 1988), who coined the term 'technology marketing', a holistic approach to ETC has been established. These works go beyond prior research, which primarily consider specific aspects, such as international licensing agreements (e.g., Lee, 1958). In the works of Ford and colleagues, the particular focus of the technology marketing perspective is on the external commercialisation of technological knowledge.

By contrast, most works in the literature concerning technology marketing do not refer to the commercialisation of disembodied knowledge but rather to the commercialisation of technology-based products (e.g., Nevens et al., 1990). In addition, some works on technology marketing refer to the external acquisition and external exploitation of technologies (Tschirky et al., 2000; Escher, 2001). However, the present paper focuses on the exploitation perspective because it has received considerably less attention than external technology acquisition, which was studied rather intensely in the 1990s (e.g., Granstrand et al., 1992; Brockhoff, 1995; Kurokawa, 1997; Veugelers and Cassiman, 1999). The term 'external technology commercialisation' is used instead of 'technology marketing' because it permits to differentiate between the internal and external mode of technology exploitation in a firm's technology marketing strategies. 
In general, technology marketing may be regarded as an essential task of strategic technology management (Nevens et al., 1990; Brockhoff, 1996; Jolly, 1997). The external mode of technology marketing, i.e., the commercialisation of technological knowledge, may be considered a complementary strategy to the internal marketing mode, i.e., product business (Ford, 1988; Brockhoff, 1999a). The major attribute of the external mode of technology marketing constitutes the fact that it refers to the commercialisation of disembodied technological knowledge. Granstrand (1998) identifies, in his technology-based theory of the firm, the following six major properties of technological knowledge in addition to its dynamically evolving nature. Technology has an artefact link, it has a science link and in general a relatively high degree of codifiability. Furthermore, it has a practical purpose, it is linked to globally oriented common systems for its operationalisation and assessment, and it may be protected by patent rights (Granstrand, 1998; 2000a).

The perspective that is applied in research into ETC goes beyond the mere outward transfer of a company's technological knowledge, which only represents the final stage of the commercialisation process. Apart from the actual transfer of the technologies, ETC includes management tasks, such as the identification of potential technology recipients, which have often been neglected in research into technology transfer. Most companies perceive major difficulties in carrying out the tasks prior to the actual knowledge transfer, especially when they try to proactively commercialise technologies (Ford and Ryan, 1977; Bidault and Fischer, 1994; Birkenmeier, 2003). Thus, the ETC perspective constitutes in this respect a more adequate framework than the mere consideration of technology transfer. In past research, ETC has often not been defined, and considerable differences in its conceptualisation may be identified. However, there are various major aspects that the prior works have in common and that may be regarded as a theoretical foundation of both the present and future studies on ETC. Therefore, important characteristics of the external mode of technology marketing will be described in the following, pointing out differences that exist in their conceptualisation in earlier works.

In ETC, the economic good is the technological knowledge itself, which is commercialised in disembodied form (Granstrand, 2000a). In this context, it is important to distinguish between companies that are offering a service and those that are externally leveraging knowledge. A company offering a service provides an intangible product, e.g., consulting services, based on its knowledge and competencies, which are not imparted to the customer. A company that externally exploits its technologies, by contrast, commercialises its knowledge, which is transferred to the ETC customers, i.e., the recipients of the technologies (Ford and Ryan, 1977). While this perspective is common to all works in the existing literature, Tschirky et al. (2000) additionally include in their framework the commercialisation of production processes through the material results of the technologies used. The definition of ETC in the present article, however, only refers to the commercialisation of disembodied technological knowledge.

Regarding the type of knowledge to be commercialised, many works in past research limit their analysis either to particular knowledge areas, mainly to technological knowledge (e.g., Ford and Ryan, 1981) or to knowledge in a particular form, mainly to knowledge protected by intellectual property rights (e.g., Anderson, 1979). The present article focuses on technology-based companies, and it takes into account technologies that are or are not protected by intellectual property rights. Thus, I build on earlier works and adopt a rather holistic perspective. Since the focus of the ETC perspective is on managing the external commercialisation activities, such an integrated approach 
seems to be appropriate because the managerial challenges are largely the same in the commercialisation of technological knowledge, which is or is not protected by intellectual property rights.

Consistent with the commercialisation of embodied knowledge, which includes the transfer of products and/or services, ETC involves inter-organisational technology transfer (Ford, 1985; Boyens, 1998), i.e., the transfer of technological knowledge from one legally and economically independent organisation to another. While the transfer of technologies between different business units or functional units of a single company may represent an ETC transaction from the perspective of a business unit or functional unit, this type of transaction does not constitute an external commercialisation of technological knowledge from a corporate perspective.

Furthermore, the external exploitation of technologies is regarded as a deliberate action of a company. Accordingly, it refers to the intended transfer of technologies and thus does not take into account the unplanned loss and leakage of information (Granstrand and Sjölander, 1990; Boyens, 1998). Due to the focus on the management tasks of the external exploitation mode, the unplanned leakage of technology is mostly excluded in the literature on ETC (Ford and Ryan, 1981; Granstrand, 2004). I follow these works and also exclude the unplanned commercialisation from further analysis.

Usually, the external exploitation of technologies is assumed to include some type of contractual obligation. While non-formal ways of externally exploiting technologies, such as informal know-how trading, are important in practice (von Hippel, 1987; Schrader, 1991), they are normally initiated by individuals and often do not follow an explicit strategic intention of the company (Boyens, 1998). As such, these non-formal types of deliberate ETC can hardly be integrated into a company's technology marketing strategy and are, therefore, also excluded from further analysis, which again is consistent with earlier works (e.g., Ford, 1985).

A contractual obligation already indicates that a company will usually receive some type of compensation for the technology transfer. In the commercialisation of products or services, monetary compensation is by far the most common form, whereas the commercialisation of disembodied knowledge offers various other possibilities, such as bi-directional technology transfers, which are frequently used in practice (Koruna, 2004). Examples are cross-licensing agreements or the mutual exchange of technologies in alliances (Brockhoff et al., 1991; Grindley and Teece, 1997).

Finally, most research approaches have adopted explicitly or by implication a process perspective on ETC (Ford and Ryan, 1981; Tschirky et al., 2000; Escher, 2001). As it has already been underlined above, the perspective of ETC puts emphasis on the management tasks in the process stages prior to the actual technology transfer. In particular, ETC includes the planning of the external commercialisation activities as well as the identification of ETC opportunities and of potential ETC customers (Ford, 1988; Tschirky et al., 2000). Besides these tasks, the ETC process comprises the negotiations with potential ETC customers, the control of the ETC activities and the actual technology transfer (Escher, 2001).

Having identified the major characteristics of the existing concepts of ETC, the meaning of the terms 'external technology commercialisation' and 'external technology exploitation' at the company level will be specified. Drawing on Boyens (1998) and Ford and Ryan (1981), external technology commercialisation and external technology exploitation are defined synonymously as follows. External Technology Commercialisation (ETC) or external technology exploitation describe an organisation's 
deliberate actions of commercialising disembodied technological knowledge to another legally and economically independent organisation involving a contractual obligation for compensation in monetary or non-monetary terms.

As the present study refers to the external commercialisation of all technological knowledge, it is not limited to knowledge protected by intellectual property rights, whose importance for ETC, however, has to be underlined. In particular, intellectual property rights may function as a facilitator of ETC activities. This argumentation has been put forward by Arora et al. (2001b), whose "analysis suggests that stronger IPRs can enhance the efficiency of technology transfers, and hence encourage the diffusion of technology, including parts of the technology that patents do not protect" (Arora et al., 2001b, p.117; see also Williamson, 1991; Kogut and Zander, 1993). The fact that intellectual property rights work particularly well in specific industries and technology areas, e.g., in the chemical industry, they have considerably contributed to the emergence of markets for technology in these fields (Levin et al., 1987; Teece, 1998; Arora and Fosfuri, 2000; Cesaroni and Mariani, 2001). Due to the facilitating function of intellectual property rights and the simultaneous importance of additional know-how, most ETC transactions include both components (Contractor, 1981; Mordhorst, 1994; Arora et al., 2001b). This is the reason why the present study does not exclusively focus on one component.

The holistic perspective that has been adopted in research into ETC is aimed at facilitating an integrated management approach to all of a firm's ETC activities. Thus, the analysis is not limited to specific types of commercialising intellectual property and additional know-how, e.g., licensing agreements. Instead, it includes different contractual forms of technology transfer to ensure an adequate coordination among the transactions as well as an appropriate coordination of the transactions with corporate strategy. Various empirical studies have taken one type of transaction as an example, usually licensing agreements (e.g., Fu and Perkins, 1995; Arora, 1997). By contrast, many theoretical approaches and some empirical studies include numerous forms of outward technology transfer (e.g., Ford, 1988; Vickery, 1988). In these cases, rather different classifications of the forms of ETC have been applied. While a part of the differences is a result of the different scope of ETC, another part arises from different degrees of detail of the classifications.

A thorough analysis of prior works in this area (e.g., Ford, 1985; Mittag, 1985; Ford, 1988; Vickery, 1988; Boyens, 1998; Granstrand, 2000a; Birkenmeier, 2003; Escher, 2003 ; 2004) shows that four major contractual forms may be distinguished: technological collaborations, licensing agreements, technology sales and the divestment of company units. The expression 'collaboration' is used for all types of inter-organisational cooperations that include technology exploitation as one of their main functions. A license, by contrast, is a permission to practice all or a part of a proprietary right that is granted by the licensor, who remains owner of the knowledge (Brooke and Skilbeck, 1994). Apart from licensing out, any technology may be sold which includes the transfer of ownership (Chiesa et al., 2003). In contrast to selling technologies, the divestment of company units does not only include the transfer of technologies but also the sale of - at least part of - the rights of disposal of a unit of the firm, including physical assets (Chesbrough, 2003b; Gassmann et al., 2003). The following section addresses the functions that the external exploitation of a firm's technological knowledge through these contractual forms may have. 


\section{Functions of external technology commercialisation}

Regarding the functions that ETC may fulfil, it has to be highlighted that both financial and strategic opportunities may be realised by commercialising disembodied knowledge. Various works in past research (e.g., Arrow, 2002; Elton et al., 2002) and many companies (Arrow, 2002; Chesbrough, 2003a) have focused on the monetary dimension and on some specific strategic aspects. Therefore, they have largely missed the variety of strategic opportunities, which may be achieved especially through a proactive use and an integrated management of ETC. Only some of the strategic functions have been intensely used in particular industries, e.g., guaranteeing freedom to operate in the semiconductors/electronics industry (Grindley and Teece, 1997), or in particular settings, e.g., realising foreign market entry through licensing at the beginning of the internationalisation process of companies (Contractor, 1980). In the following, the six main functions of ETC activities that have been identified in earlier works, above all by Koruna (2004), will be described.

1 Generating licensing revenues

The monetary dimension of ETC activities refers to generating revenues that a firm would not have realised by carrying out its current internal technology exploitation activities (Ernst, 1996; Arora, 1997; Davis and Harrison, 2001; Kline, 2003; Koruna, 2004). A good example of the revenue-generating function of ETC are the licensing revenues of IBM, which have amounted to more than \$US1.9 billion in 2001, or of Lucent Technologies, whose licensing revenues achieved more than \$US400 million in 2001 (Chesbrough, 2003c).

2 Gaining technology access

In many cases, intellectual property may be the only possibility to obtain access to another company's technology portfolio (Grindley and Teece, 1997; Rivette and Kline, 2000b; Koruna, 2004). Thus, ETC may be directed primarily at the acquisition of external technology. This function will be realised in bi-directional technology transfers based on cross licensing agreements or strategic alliance agreements (Grindley and Teece, 1997; Koruna, 2004). An example is the collaboration between Honda and General Motors, whose main objective is the mutual exchange of key technologies (Tschirky et al., 2000).

3 Setting industry standards

In some cases, a company has to find external adopters of its technology. Only by this adoption will its product business be successful (Conner, 1995; Koruna, 2004). Above all, this issue refers to the need to set an industry standard, which may be achieved by licensing a firm's particular technology (Rosenbloom and Cusumano, 1987; Boyens, 1998). For example, the active ETC approach partly explains the success of Nintendo in establishing its standard in the video game market (Arora et al., 2001b).

4 Profiting from infringements

Due to advanced information and communication technologies (Granstrand, 2000b; DeFillippi, 2002), infringements of intellectual property can be detected more easily than ever before (Rivette and Kline, 2000a; Davis and Harrison, 2001). In addition, 
companies can increasingly rely on courts in case of violation of their intellectual property rights (Granstrand, 2000a; 2004). These developments facilitate the use of ETC as a reaction to other companies' actions, which is usually called 'stick licensing' by practitioners and which refers to offering a license to infringers of a firm's technologies (Bramson, 2000; Koruna, 2004).

5 Realising learning effects

ETC activities can be a means to enhance a firm's R\&D activities as a result of learning effects (Argote, 1999; Koruna, 2004). The transfer of new technological knowledge that is developed by the recipient back to the original technology source may be formally laid down in a 'grant back' clause of a licensing agreement (Bragg and Lowe, 1989; Mordhorst, 1994; Birkenmeier, 2003). Koruna (2001) describes the case of the Swiss company Sulzer Rueti, which, as part of a joint venture, transferred technological knowledge to a Japanese competitor. Afterwards, the competitor came up with 150 ideas to improve the technology.

6 Ensuring freedom to operate

This function refers to a specific type of cross-license agreements. In those agreements, intellectual property rights are used as 'bargaining chips' (Reitzig, 2003). The main reason for this type of ETC is to avoid potential patent infringement lawsuits (Hall and Ham Ziedonis, 2001; Koruna, 2001; Reitzig, 2004). Such agreements can be found primarily in industries where companies have large patent portfolios with a high degree of technology overlap, e.g., in semiconductors and electronics (Grindley and Teece, 1997).

In practice, neither individual ETC agreements nor ETC programmes at the company level will usually have only one function. Instead, they will result from a combination of various functions (Grindley and Teece, 1997; Koruna, 2004). Although the monetary dimension is obviously regarded at least as a side aspect in most cases, it is possible to differentiate between ETC activities that are carried out mainly for monetary purposes and other ETC operations in which strategic objectives dominate. The importance of the individual strategic objectives varies substantially from industry to industry (Grindley and Teece, 1997; Arora and Fosfuri, 2000). The relevance of the functions also depends on the characteristics of the technology that is commercialised, e.g., its degree of novelty (Ford, 1988), and on contextual factors, e.g., the rate of technological change (Jaworski and Kohli, 1993; Koruna, 2004).

In the past, there has often been a focus on some individual strategic functions and on the monetary dimension in both research and practice. In recent years, however, the variety of strategic dimensions has become increasingly important (Rivette and Kline, 2000b; Davis and Harrison, 2001). To make appropriate use of the different monetary and strategic functions that ETC activities may fulfil, an appropriate managerial approach is essential. The existence of various strategic functions, e.g., gaining freedom to operate, has underlined that an integrated approach to internal and external technology exploitation is critical in order to realise the potential of successful ETC activities, which may also have important effects on a firm's product business. Therefore, an integrated approach to technology marketing will be established in the following section. 


\section{Integrated approach to technology marketing}

At the very least, the existence of markets for technology expands the strategy space because firms may choose to externally leverage their technologies either exclusively or simultaneously to their internal application. Teece (1986) pointed out that a firm should acquire complementary assets to facilitate internal technology application if it cannot appropriate rents through commercialising disembodied technological knowledge, which is worth investing in the development of additional resources. Reductions in the transaction costs in the technology markets, by contrast, increase the propensity of firms to externally exploit technologies (Arora et al., 2001b). In this regard, Arora et al. (2001b) underline that stronger intellectual property protection may be a mixed blessing for firms in technology-intensive industries. Stronger intellectual property rights raise barriers against imitation by rivals. Nevertheless, they may ultimately result in more intense competition on the product markets by facilitating technology transactions (Arora et al., 2001b).

To realise the potentials of technology marketing in general and of ETC activities in particular while minimising its risks, a company should consider its activities in this area not only as ad hoc operations, but it should develop a specific ETC strategy (Ford and Ryan, 1981; Ford, 1988; Grindley and Teece, 1997). In order to make ETC a truly strategic activity, which goes beyond the commercialisation of technologies that are not used internally, companies should take an integrated view. Thus, firms have to compare their technology assets with both internal and external exploitation opportunities (Ford and Ryan, 1981). This approach will facilitate an adequate use of the two complementary exploitation modes. "It must be emphasised that exploitation methods are not 'either-or' decisions" (Ford, 1988, p.93) and do not exclude each other.

Due to the attribute of non-rivalry of knowledge (Cornes and Sandler, 1986; Grant, 1996; Specht et al., 2002), no clear keep-or-sell decisions have to be taken in technology marketing in many cases. Rather, there are many interdependencies between the internal and external mode of technology marketing, particularly if a corporate-level view is adopted (Ford, 1988; Brockhoff, 1999a). Sometimes, the internal exploitation of a technology may even be a necessary condition for its successful external commercialisation (Arora et al., 2001a). In other cases, the external commercialisation may be a prerequisite for a successful product business (Koruna, 2004). These interdependencies are particularly important for many of the strategic functions of ETC, such as setting industry standards, which are directed at both internal and external technology marketing activities.

As a result of the complementary character of internal and external technology exploitation, these two modes of appropriating rents from technological knowledge can be regarded as two dimensions of technology marketing strategies (Figure 1). Following the work of Birkenmeier (2003), four options of commercialising technological knowledge may be distinguished, depending on the use of the internal and external commercialisation mode. 
Figure 1 Internal and external technology exploitation as alternative modes of technology marketing

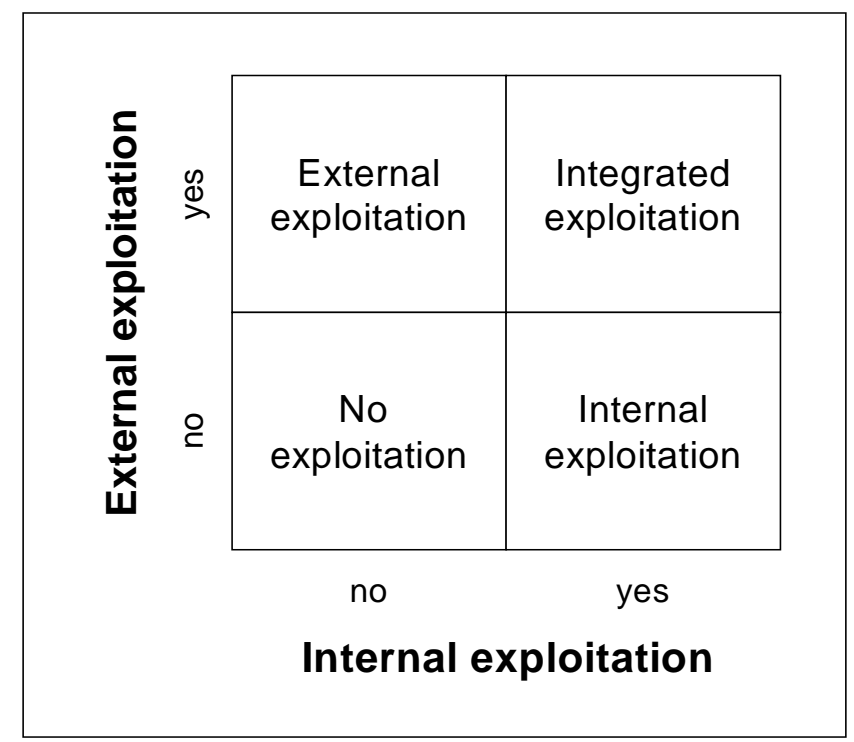

Source: Systematisation adapted from Birkenmeier (2003)

1 The option 'no exploitation' refers to situations, in which technological knowledge is neither exploited internally nor externally. Thus, the technologies are completely unused. It could be expected that non-exploitation is a rather irrelevant case in practice. However, earlier studies (e.g., Katz, 2001; Sakkab, 2002; Ernst and Omland, 2003; Kline, 2003) have shown that, often, over $50 \%$ of the patented knowledge in companies are not actively used.

2 The option 'internal exploitation' refers to situations in which a technology is only applied in a firm's products/services or in its internal processes. This exclusive use of the internal mode of technology exploitation may be considered the focus of the business strategies in most industrial firms in the past. Here, the focus is on protecting the firm's technological competencies to guarantee an exclusive use of the technologies in the firm's own products.

3 The 'external exploitation' of technologies refers to the cases in which a technology is not used in any internal processes, products or services of a firm. However, it is commercialised in disembodied form and used by the firm's ETC customers. Apart from firms, which focus on conducting contract R\&D, the purely external exploitation may be found when firms commercialise residual technology assets. Residual technology assets may result from serendipity in the R\&D process, from the uncertainty and complexity of technological developments and trends but also from changes in the firm's corporate strategy, which may render useless particular technologies for internal application. 
4 Finally, the fourth option refers to 'integrated exploitation', which describes the situation that a technology is used in a firm's internal businesses and additionally commercialised in disembodied form. Thus, the company tries to realise the benefits from internally and externally leveraging its technology assets. In fact, a part of these benefits may only be realised when simultaneously using the internal and external mode of technology marketing. With regard to the functions of ETC, an example of this option is the strategy to license out a particular technology to set an industry standard, which in turn strengthens the product business of the firm.

Due to the interdependencies between internal and external technology exploitation, a company should develop an overall technology marketing strategy, in which the different exploitation modes are coordinated (Ford and Ryan, 1981). An integrated management of internal and external technology marketing appears to be particularly important for an adequate control of the risks of ETC activities. This alignment has gained importance because in recent years many companies have started to proactively commercialise technological knowledge instead of viewing ETC merely as a residual activity (Rivette and Kline, 2000a; Kline, 2003). If ETC is an integral part of business strategy, the identification of commercialisation opportunities ideally does not only consider technologies that have already been developed and are used or not used inside the firm. Instead, it will already start during the internal development or the external acquisition of technologies in order to take the external exploitation mode into account in all major decisions regarding technology marketing (Ford and Ryan, 1981).

Thus, the external mode of technology marketing should already be considered in decisions on building up particular knowledge and in the make-or-buy decisions on developing new technologies. "[A] company must not base its development decisions on the projected returns from product sales alone. Instead, it should consider potential returns from the technology as a whole" (Ford and Ryan, 1981, p.121). For example, it might be appropriate to develop a technology internally rather than acquire it from external sources in order to realise ETC potentials. Similarly, it could be beneficial to invest some additional resources in further developing a particular technology to be able to externally leverage it. This type of systematic integration of ETC strategy into corporate strategic technology management is particularly important as there is a trend towards a closer linkage between the process of generating new technologies and the process of exploiting technologies (Brockhoff, 1998).

In addition, an integrated managerial approach to the complementary modes of technology marketing will help to adopt a holistic management of the different external exploitation activities, e.g., alliances and licensing-out agreements. This holistic approach is considered a main advantage of the ETC perspective (Ford, 1985). The specific managerial challenges that arise from carrying out multiple ETC projects simultaneously are common at the corporate level in practice (Ford, 1985; Vickery, 1988; Escher, 2003). A holistic management approach will permit a more efficient realisation of the tasks at single-project level as well as a better coordination of the tasks at multi-project level (Dyer et al., 2001; Bamford and Ernst, 2002; Lichtenthaler, 2005). Altogether, these aspects indicate that, coherent to external technology acquisition (Cohen and Levinthal, 1989; Lane et al., 2001), a company might realise economies of scale and learning effects in ETC. Finally, these effects could lead to a reduction of the transaction costs in the markets for technology. 
Although internal and external exploitation may be considered complementary at least at the corporate level, firms not only have to develop an overall ETC strategy. In many cases, companies also have to take keep-or-sell decisions for each potential ETC project, i.e., the decision to externally commercialise a particular technology or not. Firms will have to take such a decision because simultaneous internal and external technology exploitation in the same markets is beneficial only in specific situations, e.g., in settings involving network externalities. Usually, however, the internal technology exploitation potential will be reduced by externally leveraging technology assets. The opposite decision, i.e., the make-or-buy of technologies, has received considerable attention by researchers, including empirical work (e.g., Kurokawa, 1997; Veugelers and Cassiman, 1999). The keep-or-sell issue, by contrast, has been addressed in detail only in few conceptual works on the marketing of technology (e.g., Ford and Ryan, 1981; Ford, 1988; Birkenmeier, 2003). Basically, these works acknowledge that it is impossible to take general decisions on the external commercialisation of technologies and thus adopt contingency perspectives.

Ford and Ryan (1981) focus on the technology life cycle concept in the keep-or-sell decision, whereas Ford (1988) takes a broader approach by further considering the company's relative standing in the technology, the urgency of exploitation, the need for support technologies, the investment involved, potential applications and the category of the technology, i.e., its distinctiveness. According to these factors, Ford (1988) proposes four different forms of exploitation: application in own production, contracted-out manufacture or marketing, joint venture and license-out. Teece (1986) and Arora et al. (2001a) highlight the importance of the strength of the appropriability regime but put the main focus in the keep-or-sell issue on the importance of the complementary assets that are needed for commercialising technologies in own products. Koruna (2004) further details the analysis of the technology to be commercialised by differentiating between product and process technologies. In addition, Birkenmeier (2003) proposes the functional relevance of technologies as an additional factor of influence on the keep-or-sell decision by distinguishing between core technologies, support technologies and functionally irrelevant technologies.

With regard to applying the transaction cost approach to the keep-or-sell decision, it has to be emphasised that internal and external technology marketing usually represent complementary exploitation modes (Ford, 1988; Brockhoff, 1999a) and that ETC normally involves both monetary and strategic benefits (Koruna, 2004). Moreover, the aim to reach an overall optimum has to be highlighted from a firm-level perspective because the local rationality of optimising every single technology transaction may have a negative impact on a firm's corporate technology strategy due to the potential positive and negative synergies between multiple ETC transactions (Lichtenthaler and Lichtenthaler, 2004). Thus, these aspects additionally complicate the application of the traditional transaction cost perspective.

To sum up, it has to be underlined that no comprehensive framework for the keep-or-sell decision in ETC, e.g., an adapted transaction cost approach, has emerged yet. The role of the specific technology has been addressed in relative detail, whereas numerous other factors have largely been ignored. As a result of the high complexity and context-dependency of the decision, it will be very difficult to develop a comprehensive framework, which has been intended by Ford (1988). To implement appropriate keep-or-sell decisions in practice, it might be more important to establish a general ETC strategy, which is closely aligned with the firm's internal technology 
marketing strategies. Based on this overall strategy and on the main functions of the multi-project ETC programme, keep-or-sell decisions for specific technologies may be taken. Due to the interdependencies between internal and external technology exploitation, a holistic approach to technology marketing may be considered an essential part of a firm's technology strategy. Against the background of an increasing use of the external exploitation mode in practice, an integrated management of the technology marketing activities may constitute an important source of competitive advantage in the future.

\section{Discussion}

Past research into technology marketing has largely focused on the commercialisation of technologies via the sale of a firm's products. The possibility to commercialise disembodied technological knowledge, by contrast, has often been neglected in both theory and practice. Nevertheless, an increase in ETC activities in many firms could be observed in recent years (Davis and Harrison, 2001; Chesbrough, 2003c; Kline, 2003). This increase is particularly remarkable because of the strong imperfections inherent to the markets for technology (Teece, 1981; Caves et al., 1983; Arora et al., 2001b). Some pioneering firms in this area realise great benefits from externally leveraging their technology assets. The most popular example of a company that realises enormous monetary and strategic benefits through its ETC activities is IBM, whose intellectual property revenues amounted to more than \$US1.7 billion in 2000, up from \$US30 million in 1990 (Rivette and Kline, 2000b; Chesbrough, 2003c; Kline, 2003). These revenues made up roughly $20 \%$ of IBM's net income in that year and were realised - according to the calculations of IBM - with a $98 \%$ profit margin (Kline, 2003). As IBM's intellectual property revenues have remained at a very high level in recent years (Chesbrough, 2003c; IBM, 2004), these numbers do not seem to be the result of one-time effects.

By contrast, the majority of firms perceive great difficulties in appropriately managing their ETC activities (Tschirky et al., 2000; Birkenmeier, 2003; Escher, 2003). These difficulties lead to an under-utilisation of the ETC potentials in most industrial firms. Elton et al. (2002) have found that only a small number of the more than 40 larger companies that they studied earned more than $0.5 \%$ of their operating income from licensing although their technology portfolios usually would allow this rate to be between $5 \%$ and $10 \%$. Various sources show that often over $50 \%$ of corporate technology assets are not used in internal technology exploitation (Katz, 2001; Sakkab, 2002; Ernst and Omland, 2003; Kline, 2003). Although normally not all of a company's unused technologies may be externally exploited, at least about $10 \%$ of a firm's patent portfolio may usually be commercialised for monetary purposes alone (Elton et al., 2002). Various studies point to considerable difficulties of firms in making appropriate use of the external commercialisation mode (Elton et al., 2002; Birkenmeier, 2003).

"[C]ompanies trying to imitate the success story of, for example, IBM's licensing program, often fail to initiate such a (sic!) deployment program due to market imperfections and the necessary high initial financial commitment." (Escher, 2003, p.215) 
Thus, the growing extent of ETC activities in general and the enormous benefits of some firms in particular are complemented by the rather contradictory situation that the majority of firms experience great problems in managing its ETC activities successfully. As a result, most firms fail to realise the value inherent to their technology assets, leaving great potentials for improving their ETC activities. A major issue in this regard is to become aware of the large potentials that ETC may offer. Thus, the present article attempts to balance the focus of most prior works on internal technology exploitation by highlighting the importance of the external exploitation mode. The analysis of the functions of ETC activities has shown that firms may pursue both monetary and strategic objectives when externally leveraging technologies. Due to the interdependencies between internal and external technology marketing, many of these functions may only be achieved if the ETC activities are appropriately coordinated with a firm's product business. Thus, a major challenge of technology marketing in general and of successful ETC activities in particular may be seen in adequately aligning internal and external technology marketing activities. The lack of an integrated approach may be considered a major underlying reason for the severe difficulties that many firms experience in their ETC operations.

Coordinating a firm's ETC strategy with the other activities requires, in the first step, a strategic approach to ETC, which has already been proposed by Ford and Ryan (1981). However, prior research has found that ETC activities are often still regarded as ad hoc operations in practice. Consistent with other findings (Fu and Perkins, 1995; Escher, 2004), Birkenmeier's (2003) empirical analysis has shown that $49 \%$ of the companies that he studied during the 1990s did not address ETC in a strategic and systematic way. In contrast to the pioneering firms in ETC, many companies, particularly smaller ones, lacked actual strategies for their ETC activities but planned to systematise their approaches in the future (Birkenmeier, 2003). Due to the imperfections inherent to the markets for technology, networks and personal contacts have often played a key role in initiating ETC transactions which has supported a rather informal approach to ETC (Bidault and Fischer, 1994; Fu and Perkins, 1995). This relative lack of a systematic approach may be considered a severe deficit, which prevents firms from achieving their objectives in ETC and in technology marketing in general.

Additional support for this interpretation may be found in the results of a recent study by Escher (2004), who has carried out case studies in 18 firms. The diversity across these 18 companies is extremely high because the sample included small technology-oriented companies, which focus on ETC, as well as large firms, which focus on the commercialisation of products. With regard to the role of ETC in the firms, Escher (2004) has distinguished three categories of companies. The first category refers to firms that use ETC as their main business. As this is a very special case, this type of firms is not included in the analysis of the present paper. The second group comprises firms that use ETC as an additional business, which however, is carried out continuously. The third group refers to firms that pursue ETC activities only occasionally.

Differentiating between the second and third category of firms is essential because the second group of firms sees a large ETC potential and carries out ETC activities continuously. Due to the higher relevance of these activities, it may be expected that ETC is aligned rather strongly with the internal technology exploitation activities. Thus, these companies may be able to realise synergies and learning effects in this area, which help the firms to achieve the monetary and strategic potential inherent to their ETC activities. The third group of firms, by contrast, considers their ETC activities merely as an 
occasional business. This does not mean that these firms ignore the external exploitation mode. However, they approach ETC in a less systematic way. Obviously, the ETC activities are not closely linked to corporate strategy in these firms. Rather, the firms take advantage of specific promising ETC opportunities in a more opportunistic way (Escher, 2004). Accordingly, their technology marketing approach appears to be considerably less integrated than the approach of the firms in the second category.

Accordingly, these results underline that the integration of ETC activities into the overall corporate strategy of a firm may have a positive direct impact on the firm's ETC performance. Moreover, the results of Escher (2004) point to the situation that the role of ETC in the companies also has additional indirect effects. For example, firms with an integrated technology management approach tend to have a more systematic process for their ETC activities, particularly regarding an appropriate control of the ETC activities (Escher, 2004). Due to the potential importance of ETC activities for a firm's product business, these consequences of an integrated approach to technology marketing may have indirect positive effects on a firm's performance in internal and external technology exploitation. Thus, an integrated approach may be an essential determinant of successfully commercialising a firm's technologies. Its impact may be expected to gain additional strength in the future due to the trend towards a closer linkage between the process of generating new technologies and the process of exploiting this knowledge (Brockhoff, 1998).

\section{Conclusion}

In the present paper, it has been shown that some firms realise enormous benefits by externally leveraging technology assets, whereas many companies experience major difficulties when they try to actively use the external exploitation mode. Despite these difficulties, a substantial increase in ETC could be observed in recent years. These two facts point to a strong need of research into ETC. Therefore, the present paper has focused on ETC as a mode of technology marketing that is complementary to the application of technologies in a firm's own products or services. Based on an analysis of the existing literature, the characteristics of the ETC perspective have been detailed. Moreover, the variety of strategic and monetary functions that ETC activities may have has been highlighted. Thus, the present article may help to balance the focus of prior works on internal technology application. Above all, the analysis of the functions of ETC activities has underlined the strong interdependencies between internal and external technology commercialisation.

Thus, an integrated approach to technology marketing has been established. It could be shown that firms should develop an overall technology marketing strategy. Based on this overall strategy at the corporate level, which takes into account all of a firm's ETC projects, companies may take keep-or-sell decisions for individual ETC transactions. Accordingly, this article considerably extends prior works by focusing on the external mode of technology marketing, identifying its major functions and developing an integrated strategic approach, which allows to incorporate firm-level and project-level issues. This approach is limited to theoretical considerations, but it is supported by various past research results. In particular, it may help us to develop a deeper understanding of the contradictory situation that some firms realise enormous benefits 
while most others experience major difficulties in their ETC activities. Thus, the existence of an integrated approach to technology marketing may provide a useful theoretical lens for examining inter-firm differences in the management and performance of ETC activities.

To overcome the conceptual stage, results of prior empirical research have been used in the discussion to provide support for the theoretical framework. In addition, the concept of an integrated technology marketing approach offers great opportunities for future research, which will help to validate and refine the theoretical concept. Thus, the present article may serve as a basis for further conceptual and empirical work. Further research into ETC, which includes tasks prior to the actual technology transfer, may lead to research results that constitute an essential complement to existing studies on technology transfer, particularly for companies that try to proactively commercialise technologies. Thus, future research may considerably contribute to a more effective technology exploitation in companies. As much remains to be explored, further research into technology marketing in general and into ETC in particular will be essential against the background of an increasing commercialisation of technological knowledge. The integrated approach to technology marketing appears to be an appropriate starting point for future works, which may lead to interesting insights that are valuable for both research and practice.

\section{References}

Amesse, F. and Cohendet, P. (2001) 'Technology transfer revisited from the perspective of the knowledge-based economy', Research Policy, Vol. 30, pp.1459-1478.

Anderson, B.A. (1979) 'Acquiring and selling technology - marketing techniques', Research Management, Vol. 22, No. 2, pp.26-28.

Argote, L. (1999) Organizational Learning: Creating, Retaining and Transferring Knowledge, Boston: Kluwer.

Arora, A. (1997) 'Patents, licensing, and market structure in the chemical industry', Research Policy, Vol. 26, pp.391-403.

Arora, A. and Fosfuri, A. (2000) 'The market for technology in the chemical industry: causes and consequences', Revue d'economie industrielle, No. 92, pp.317-334.

Arora, A., Fosfuri, A. and Gambardella, A. (2001a) 'Markets for technology and their implications for corporate strategy', Industrial and Corporate Change, Vol. 10, No. 2, pp.419-451.

Arora, A., Fosfuri, A. and Gambardella, A. (2001b) Markets for Technology: the Economics of Innovation and Corporate Strategy, Cambridge: MIT Press.

Arrow, A.K. (2002) 'Intangible asset deployment in technology-rich companies: how does innovation affect return on assets?', International Journal of Technology Management, Vol. 24, No. 4, pp.375-390.

Bamford, J. and Ernst, D. (2002) 'Managing an alliance portfolio', McKinsey Quarterly, No. 3, pp.29-39.

Bidault, F. and Fischer, W.A. (1994) 'Technology transactions: networks over markets', $R \& D$ Management, Vol. 24, No. 4, pp.373-386.

Birkenmeier, B. (2003) Externe Technologie-Verwertung: Eine komplexe Aufgabe des Integrierten Technologie-Managements, PhD Dissertation No. 15240, Zurich: ETH.

Boyens, K. (1998) Externe Verwertung von technologischem Wissen, Wiesbaden: Dt. Univ.-Verl.

Bragg, R.J. and Lowe, A.V. (1989) The Business of Licensing, Harlow: Longman.

Bramson, R.S. (2000) Some Comparisons of and Comments about Carrot and Stick Licensing, Working Paper. 
Brockhoff, K. (1995) 'Zur Theorie des externen Erwerbs neuen technologischen Wissens', ZfB-Ergänzungsheft 1, pp.27-42.

Brockhoff, K. (1996) 'Technology management in the company of the future', Technology Analysis and Strategic Management, Vol. 8, No. 2, pp.175-189.

Brockhoff, K. (1998) 'Technology management as part of strategic planning - some empirical results', $R \& D$ Management, Vol. 28, pp.129-138.

Brockhoff, K. (1999a) Forschung und Entwicklung, Planung und Kontrolle, München/Wien: Oldenbourg.

Brockhoff, K. (1999b) 'Zum Transfer von Ergebnissen öffentlicher Grundlagenforschung in die Wirtschaft', Zeitschrift für Betriebswirtschaft, Vol. 69, pp.1331-1350.

Brockhoff, K., Gupta, A.K. and Rotering, C. (1991) 'Inter-firm R\&D cooperations in Germany', Technovation, Vol. 11, pp.219-230.

Brooke, M.Z. and Skilbeck, J.M. (1994) Licensing, Aldershot/Brookfield: Gower.

Caves, R.E., Crookell, H. and Killing, P. (1983) 'The imperfect market for technology licenses', Oxford Bulletin of Economics and Statistics, Vol. 45, pp.249-267.

Cesaroni, F. and Mariani, M. (2001). 'The market for knowledge in the chemical sector', in B. Guilhon (Ed.) Technology and Markets for Knowledge: Knowledge Creation, Diffusion and Exchange within a Growing Economy, Boston/Dordrecht/London: Kluwer Academic Publishers.

Chesbrough, H. (2003a) 'The era of open innovation', MIT Sloan Management Review, Vol. 44, No. 3, pp.35-41.

Chesbrough, H. (2003b) 'The governance and performance of Xerox's technology spin-off companies', Research Policy, Vol. 32, pp.403-421.

Chesbrough, H. (2003c) 'The logic of open innovation: managing intellectual property', California Management Review, Vol. 45, No. 3, pp.33-58.

Chiesa, V., Manzini, R. and Pizzurno, E. (2003) 'The market for technological intangibles: a conceptual framework for the commercial transactions', Proceedings of the $R \& D$ Management Conference, pp.1-10.

Chiesa, V., Manzini, R. and Pizzurno, E. (2004) 'The externalisation of R\&D activities and the growing market of product development services', R\&D Management, Vol. 34, No. 1, pp.65-75.

Cohen, W.M. and Levinthal, D.A. (1989) 'Innovation and learning: the two faces of R\&D', The Economic Journal, Vol. 99, pp.569-596.

Conner, D.R. (1995) 'Obtaining strategic advantage from being imitated: when can encouraging “clones” pay?', Management Science, Vol. 41, No. 2, pp.209-225.

Contractor, F.J. (1980) 'The "profitability" of technology licensing by U.S. multinationals: a framework for analysis and an empirical study', Journal of International Business Studies, Vol. 11, No. 2, pp.40-63.

Contractor, F.J. (1981) International Technology Licensing: Compensation, Costs, and Negotiation, Lexington: Lexington Books.

Cornes, R. and Sandler, T. (1986) The Theory of Externalities, Public Goods, and Club Goods, Cambridge: Cambridge University Press.

Davis, J.L. and Harrison, S.S. (2001) Edison in the Boardroom: How Leading Companies Realize Value from Their Intellectual Assets, New York: John Wiley and Sons.

DeFillippi, R.J. (2002) 'Organizational models for collaboration in the new economy', Human Resource Planning, Vol. 25, No. 4, pp.7-18.

Dyer, J.H., Kale, P. and Singh, H. (2001) 'How to make strategic alliances work', MIT Sloan Management Review, Vol. 42, No. 4, pp.37-43.

Elton, J.J., Shah, B.R. and Voyzey, J.N. (2002) 'Intellectual property: partnering for profit', McKinsey Quarterly, 2002 Special Edition, pp.58-67. 
Ernst, H. (1996) Patentinformationen für die strategische Planung von Forschung und Entwicklung, Wiesbaden: Dt. Univ.-Verl.

Ernst, H. (1998) 'Industrial research as a source of important patents', Research Policy, Vol. 27, pp.1-15.

Ernst, H. and Omland, N. (2003) 'Patentmanagement in jungen Technologieunternehmen', Zfb-Ergänzungsheft 2, Vol. 67, pp.95-113.

Escher, J-P. (2001) 'Process of external technology exploitation as part of technology marketing: a conceptual framework', Proceedings of the PICMET Conference.

Escher, J-P. (2003) 'Design and implementation of technology marketing organizations, in $\mathrm{H}$. Tschirky, H-H. Jung and P. Savioz (Eds.) Technology and Innovation Management on the Move, Zurich: Orell Füssli.

Escher, J-P. (2004) 'Technology marketing in technology-based enterprises - the process and organization structure of external technology deployment', PhD dissertation No. 15886, Zurich: ETH.

Ford, D. (1985) The management and marketing of technology', in R. Lamb and P. Shrivastava (Eds.) Advances in Strategic Management, London: JAI Press.

Ford, D. (1988) 'Develop your technology strategy', Long Range Planning, Vol. 21, No. 5, pp.85-95.

Ford, D. and Ryan, C. (1977) 'The marketing of technology', European Journal of Marketing, Vol. 11, No. 6, pp.369-382.

Ford, D. and Ryan, C. (1981) 'Taking technology to market', Harvard Business Review, Vol. 59, No. 2, pp.117-126.

Fu, S. and Perkins, D.S. (1995) 'Technology licensors and licensees: who they are, what resources they employ, and how they feel', International Journal of Technology Management, Vol. 10, Nos. 7-8, pp.907-920.

Gans, J.S. and Stern, S. (2003) 'The product market and the market for "ideas": commercialization strategies for technology entrepreneurs', Research Policy, Vol. 32, pp.333-350.

Gassmann, O., Escher, J-P. and Luggen, M. (2003) 'Technologieverwertung durch Spin-off: Ausgründungen aus privatwirtschaftlichen Forschungszentren', Wissenschaftsmanagement, Vol. 5, No. 5, pp.24-30.

Granstrand, O. (1998) 'Towards a theory of the technology-based firm', Research Policy, Vol. 27, pp.465-489.

Granstrand, O. (2000a) The Economics and Management of Intellectual Property: Towards Intellectual Capitalism, Northampton: Edward Elgar Publishing.

Granstrand, O. (2000b) 'The shift towards intellectual capitalism - the role of infocom technologies', Research Policy, Vol. 29, pp.1061-1080.

Granstrand, O. (2004) 'The economics and management of technology marketing: towards a pro-licensing era?', International Journal of Technology Management, Vol. 27, Nos. 2-3, pp.209-240.

Granstrand, O. and Sjölander, S. (1990) 'Managing innovation in multi-technology corporations', Research Policy, Vol. 19, pp.35-60.

Granstrand, O., Bohlin, E., Oskarsson, C. and Sjöberg, N. (1992) 'External technology acquisition in large multi-technology corporations', $R \& D$ Management, Vol. 22, No. 2, pp.111-133.

Grant, R.M. (1996) 'Toward a knowledge-based theory of the firm', Strategic Management Journal, Winter, Vol. 17, pp.109-122.

Grindley, P.C. and Teece, D.J. (1997) 'Managing intellectual capital: licensing and cross-licensing in semiconductors and electronics', California Management Review, Vol. 39, No. 2, pp.8-41.

Guilhon, B., Attia, R. and Rizoulières, R. (2004) 'Markets for technology and firms' strategies: the case of the semiconductor industry', International Journal of Technology Management, Vol. 27, Nos. 2-3, pp.123-142. 
Hall, B. and Ham Ziedonis, R. (2001) 'The determinants of patenting in the US semiconductor industry, 1980-1994', RAND Journal of Economics, Vol. 32, pp.101-128.

Hansen, M.T. (2002) 'Knowledge networks: explaining effective knowledge sharing in multiunit companies', Organization Science, Vol. 13, No. 3, pp.232-248.

Hoegl, M., Parboteeah, K.P. and Munson, C.L. (2003) 'Team-level antecedents of individuals' knowledge networks', Decision Sciences, Vol. 34, No. 4, pp.741-770.

Hwang, A-S. (2004) 'Integrating technology, marketing and management innovation', Research Technology Management, Vol. 47, No. 4, pp.27-31.

IBM (2004) Annual Report.

Jaworski, B.J. and Kohli, A.K. (1993) 'Market orientation: antecedents and consequences', Journal of Marketing, Vol. 57, pp.53-70.

John, G., Weiss, A.M. and Dutta, S. (1999) 'Marketing in technology-intensive markets: toward a conceptual framework', Journal of Marketing, Vol. 63, pp.78-91.

Jolly, V.K. (1997) Commercializing New Technologies: Getting from Mind to Market, Boston: Harvard Business School Press.

Katz, D.M. (2001) A Company's Mind is a Terrible Thing to Waste, http://www.cfo.com/ article/1,5309,4335III1,00.html, July 26, Checked: 01.06.2005.

Kline, D. (2003) 'Sharing the corporate crown jewels', MIT Sloan Management Review, Vol. 44, No. 3, pp.89-93.

Kogut, B. and Zander, U. (1993) 'Knowledge of the firm and the evolutionary theory of the multinational corporation', Journal of International Business Studies, Vol. 24, pp.625-645.

Koruna, S. (2001) 'External technology commercialization: policy guidelines', Proceedings of the PICMET Conference.

Koruna, S. (2004) 'External technology commercialization - policy guidelines', International Journal of Technology Management, Vol. 27, Nos. 2-3, pp.241-254.

Kurokawa, S. (1997) 'Make-or-buy decisions in R\&D: small technology based firms in the United States and Japan', IEEE Transactions on Engineering Management, Vol. 44, No. 2, pp.124-134.

Lan, P. (2000) 'The technology-component matrix: a tool for analysing and managing knowledge', International Journal of Technology Management, Vol. 20, Nos. 5-8, pp.670-683.

Lane, P.J., Salk, J.E. and Lyles, M.A. (2001) 'Absorptive capacity, learning, and performance in international joint ventures', Strategic Management Journal, Vol. 22, pp.1139-1161.

Lee, C.H. (1958) 'How to reach the overseas market by licensing', Harvard Business Review, Vol. 36, No. 1, pp.77-81.

Levin, R.C., Klevorick, A.K., Nelson, R.R. and Winter, S.G. (1987) 'Appropriating the returns from industrial research and development', Brookings Papers on Economic Activity, Vol. 3, pp.783-820.

Lichtenthaler, U. (2005) 'Management of multi-R\&D-alliance processes in international companies: a conceptual framework', International Journal of Technology Transfer and Commercialisation, Vol. 4, No. 4, pp.439-461.

Lichtenthaler, U. and Lichtenthaler, E. (2004) 'Alliance functions: implications of the international multi-R\&D-alliance perspective', Technovation, Vol. 24, No. 7, pp.541-552.

Lien, A.P. (1979) 'Acquiring and selling technology: the role of the middleman', Research Management, Vol. 22, No. 2, pp.29-31.

Marcy, W. (1979) 'Acquiring and selling technology - licensing do's and don'ts', Research Management, Vol. 22, No. 3, pp.18-21.

Mittag, H. (1985) Technologiemarketing: Die Vermarktung von industriellem Wissen unter besonderer Berücksichtigung des Einsatzes von Lizenzen, Bochum: Studienverlag Brockmeyer. 
Mordhorst, C.F. (1994) Ziele und Erfolg unternehmerischer Lizenzstrategien, Wiesbaden: Dt. Univ.-Verl.

Nevens, T.M., Summe, G.L. and Uttal, B. (1990) 'Commercializing technology: what the best companies do', Harvard Business Review, Vol. 68, No. 3, pp.154-163.

Reitzig, M. (2003) 'What determines patent value? Insights from the semiconductor industry', Research Policy, Vol. 32, pp.13-26.

Reitzig, M. (2004) 'Strategic management of intellectual property', MIT Sloan Management Review, Vol. 45, No. 3, pp.35-40.

Rivette, K.G. and Kline, D. (2000a) 'Discovering new value in intellectual property', Harvard Business Review, Vol. 78, No. 1, pp.54-66.

Rivette, K.G. and Kline, D. (2000b) Rembrandts in the Attic: Unlocking the Hidden Value of Patents, Boston: Harvard Business School Press.

Rosenbloom, R.S. and Cusumano, M.A. (1987) 'Technological pioneering and competitive advantage: the birth of the VCR industry', California Management Review, Vol. 29, pp.51-76.

Ruggles, R. (1998) 'The state of the notion: knowledge management in practice', California Management Review, Vol. 40, No. 3, pp.80-89.

Sakkab, N.Y. (2002) 'Connect and develop complements: research and develop at P\&G', Research Technology Management, Vol. 45, pp.38-45.

Scarbrough, H. and Swan, J. (2001) 'Explaining the diffusion of knowledge management: the role of fashion', British Journal of Management, Vol. 12, pp.3-12.

Schrader, S. (1991) 'Informal technology transfer between firms: cooperation through information trading', Research Policy, Vol. 20, pp.153-170.

Specht, B., Beckmann, C. and Amelingmeyer, J. (2002) F\&E-Management: Kompetenz im Innovationsmanagement, Stuttgart: Schäffer-Poeschel.

Sullivan, P.H. and Fox, S.P. (1996) 'Establishing an out-licensing activity', in R.L. Parr and P.H. Sullivan (Eds.) Technology Licensing: Corporate Strategies for Maximizing Value, New York: John Wiley and Sons.

Teece, D.J. (1981) 'The market for know-how and the efficient international transfer of technology', Annals of the Academy of Political and Social Science, Vol. 458, pp.81-96.

Teece, D.J. (1986) 'Profiting from technological innovation: implications for integration, collaboration, licensing and public policy', Research Policy, Vol. 15, pp.285-305.

Teece, D.J. (1998) 'Capturing value from knowledge assets: the new economy, markets for know-how, and intangible assets', California Management Review, Vol. 40, No. 3, pp.55-79.

Tschirky, H., Escher, J-P., Tokdemir, D. and Belz, C. (2000) 'Technology marketing: a new core competence of technology-intensive enterprises', International Journal of Technology Management, Vol. 20, Nos. 3-4, pp.459-474.

Uslay, C., Malhotra, N.K. and Citrin, A.V. (2004) 'Unique marketing challenges at the frontiers of technology: an integrated perspective', International Journal of Technology Management, Vol. 28, No. 1, pp.8-30.

Veugelers, R. (1997) 'Internal R\&D expenditures and external technology sourcing', Research Policy, Vol. 26, pp.303-315.

Veugelers, R. and Cassiman, B. (1999) 'Make and buy in innovation strategies: evidence from Belgian manufacturing firms', Research Policy, Vol. 28, No. 1, pp.63-80.

Vickery, G. (1988) 'A survey of international technology licensing', STI Review, No. 4, pp.7-49.

von Hippel, E. (1987) ‘Cooperation between rivals: informal know-how trading', Research Policy, Vol. 16, pp.291-302.

Williamson, O.E. (1991) 'Comparative economic organization - the analysis of discrete structural alternatives', Administrative Science Quarterly, Vol. 36, No. 4, pp.269-296. 